\title{
A COMPARISON OF ELECTRICITY INDUSTRY REGULATION AND RESTRUCTURING: GREECE AND TURKEY
}

Yeşim REEL"

\begin{abstract}
The main aim of this paper is to compare the experience of regulation and restructuring in the Greek and the Turkish electricity industries. For this purpose, a comparison of data on the two industries is employed. A quantitative analysis of the impact of restructuring these two countries' presented and complemented with an evaluation of relevant legislation, policy changes and regulation scores. The paper shows that the electricity industries in Turkey and Greece have undergone a radical restructuring, but which remains an ongoing process. The main conclusion is that the two industries face number of challenges, and that institutional and political reforms ensuring the smooth functioning of the electricity industries thus need to be enacted. In addition, there is a crucial need for a debate about regulatory principles for the industry in both countries.
\end{abstract}

Keywords: Electricity industry, regulation, restructuring, Greece, Turkey

\section{ELEKTRİK ENDÜSTRISİ REGÜLASYONU VE YENIDEN YAPILANMASINA DAİR BİR KARŞILAŞTIRMA: YUNANISTAN VE TÜRKIYYE}

$\ddot{O} z$

Bu makalenin amacl, Yunanistan ve Türk elektrik endüstrilerinin regülasyon ve yeniden yapılanma tecrübelerinin karşılaştırılmasıdır. Bu amaca yönelik söz konusu iki endüstrinin verilerinin karşılaştırılması tercih edildi. Bu endüstrilerdeki yeniden yaplanmanin etkisi niceliksel analizle gösteriliyor. Bu analiz, iki ülkenin elektrik endüstrilerindeki yasal ve politika değişimleri ile regülasyon skorların kapsayan bir değerlendirmeyle tamamlanmaktadır. Makale, hem Türkiye hem de Yunanistan'daki elektrik endüstrilerinin radikal yeniden yapılanma içinde

\footnotetext{
"Asst. Prof. (PhD), Marmara University, Department of Economics, e-mail: yesimreel@marmara.edu.tr
} 
bulunduklarını ve bu sürecin hala devam ettiğini göstermektedir. Makalenin en önemli sописи söz konusu elektrik endüstrilerinin çok sayıda problem ile karşı karşıya olduğudur. Dolaylsıyla, bu iki elektrik endüstrisinin gerektiği şekilde işleyişinin sağlanabilmesi için kurumsal ve politik reformlara devam edilmesi gerekmektedir. Buna ilave olarak, Yunanistan ve Türk elektrik endüstrilerinin regülasyon prensipleri üzerine ciddi bir tartışmanın yürütülmesi de elzemdir.

Anahtar Kelimeler: Elektrik endüstrisi, regülasyon, yeniden yapılanma, Yunanistan, Türkiye

\section{Introduction}

Many countries from different regions and income levels have initiated a restructuring of their electricity industries since the 1980s, and for a variety of motives (Camadan, 2011: 70). While operation of the electricity sector has been performed by the private sector subject to regulation since the development of electricity supply, such activities of the electricity sector have historically been considered a public service in Europe and performed by the state. In general, prices have been determined below the actual costs of production and delivery and used as a medium for economic and social policies. From the 1980s, however, along with advancements in turbine technology and developments in the information sector, there has been widespread adoption and application of the idea that competition is possible and economically efficient at the level of production. Finally, in many countries across the world, it has been recognised that the traditional vertically integrated structure of the sector can be done away with also, the industry separated and competition established at the production level employed to set up a structure whereby network activities may be rearranged through the implementation of market reforms (EMRA, 2010: 51).

In many countries, electricity services have been provided by vertically integrated enterprises operating as publicly owned monopolies that encompass generation, transmission and distribution activities. Many power sector reform programmes, particularly in those countries where the power industry has been organised, as it is in Turkey and Greece, have therefore been focused on moving from a monopoly to either a single buyer model (SBM) or directly to a wholesale competition model.

The Greek electricity industry is an example of such structural reform. Many of the changes incorporated in a 1999 law there were made to comply with Greece's obligations under the EU Electricity Directive (OECD, 2001a: 24), with the initial market design year for Greece set at 2001. Meanwhile, in February 2001, Turkey passed its long-anticipated Electricity Market Law, paving the way for a free market in power generation and distribution. This came in the context of Turkey's effort to join the EU, which also included the incorporation of numerous EU energy laws and standards into the country's national energy legislation. 
Furthermore, at a transnational level, greatly improved relations between Greece and Turkey enabled not only an economic but also energy cooperation (Koroneos and Nanaki, 2007: 3826-3827).

The main purpose of this paper is to compare the experience of regulation and restructuring in the Greek and the Turkish electricity industries. These two national industries are taken as case studies because the timing of their initial market designs (2001) and the main reason for their reforms (EU obligations) were the same, while their energy cooperation is also important and, furthermore, both countries are still in the transitional period. ${ }^{1}$

Investigating issues around this, the present paper is composed of five sections. The first section details the research methodology. The second section examines thepolicy changes, characteristics and performance of the Greek electricity industry and the third section does the same for the Turkish electricity industry. The fourth section provides a comparison of the experience of regulation and restructuring in the Greek and the Turkish electricity industries, with some concluding remarks offered in the last section.

\section{Research Methodology}

Jamasb et al. (2004) and other scholars emphasise that there is a deficiency of generally accepted and measured indicators with which to examine the progress, impacts and performance of electricity sector reforms. Since the aim of this paper is to compare the regulation and restructuring experience of the Turkish and Greek electricity sectors, the same deficiency is encountered. Therefore, instead of using an econometric model, a comparison and evaluation of data on the Turkish and Greek electricity sectors is employed. The impact of restructuring in these industries is presented using a quantitative analysis of (i) performance of recent price levels (for household consumers and industrial consumers); (ii) market structure (market share of the largest generator, number of main electricity generating companies and degree of market opening); and (iii) degree of private involvement. The quantitative analysis is complemented with an evaluation, which includes legislation and policy changes and regulation scores for the two countries' electricity industries.

The electricity data was collected from various international sources, including Eurostat, Eurelectric, the OECD and IEA, along with MENR (Ministry of Energy and Natural Resources) and EMRA (Energy Market Regulatory Authority) from Turkey and also various articles and papers. Data is supplied for as late as 2013.

\footnotetext{
${ }^{1}$ Although two countries have come to the end of transitional period in theory, they have not yet coped with all the transitional problems (see below).
} 


\section{Policy Changes, Characteristics and Performance of the Greek Electricity Industry}

\subsection{Policy Changes}

Reform in the electricity sector in Greece is mainly driven by its obligations under EU rules for the internal market for electricity (OECD, 2001b, 40). The development of a liberalised electricity market in here began with the enactment of Law 2773/1999, harmonising national legislation with the EU Directive 96/92/EC. This law established new entities within the electricity sector in the country, including the Regulatory Authority for Energy (RAE) and the Hellenic Transmission System Operator (HTSO), as well as gave general directions for the creation of a competitive electricity market. The initial market design in the year 2001 was not considered successful, at least in terms of opening the market to new players, because of the existence of the incumbent utility, the Public Power Corporation (PPC), with a market share of over $99 \%$ in both generation and supply (Sakellaris et al., 2010: 1).

The state-owned PPC was created in 1950 as a vertically integrated company, with $49 \%$ of its publically issued shares held by institutional investors, including $4 \%$ held by the PPC employee insurance fund, and the remainder belonging to the Greek state, which was legally bound to remain the majority shareholder (Iliadou, 2009: 80). The PPC retained its dominant position through to 2010 (RAE, 2011: 20). The PPC retail market share fell from $100 \%$ in 2009 to approximately $92.3 \%$ in 2011, but by 2012 it had recovered to $98.5 \%$ (Kalantzis \& Sakellaris, 2012: 3, Danias et al., 2013: 1043).

According to the initial provisions of Law 2773/1999, legal unbundling was introduced only for the operation of the transmission system. The related responsibilities were assigned to the Hellenic Transmission System Operator S.A. (HTSO), a majority state-owned company, with $49 \%$ of its shares belonging to the PPC. Then, as provided by Law 3426/2005, in July 2007, the HTSO also acquired the responsibility for operation of the distribution network, with exception of that located on the non-interconnected islands; HTSO was then renamed the Hellenic Transmission and Distribution Systems Operator (HTDSO) (Iliadou, 2009: 80).

As the Greek electricity market featured one dominant player, the PPC, controlling about $95 \%$ of the generation market and $100 \%$ of the supply market, it was deemed important from the beginning to design a market that would facilitate the entrance of new participants and restrict the PPC's dominant market power (RAE, 2010: 32). The Greek wholesale electricity market has been organised as a pure mandatory pool since its inception in 2005, but after gradual refinements, a transitional market design, implemented over a five-year period, was substituted on $30^{\text {th }}$ September 2010 in its (provisionally) final form. The revised market design, known as the ' $5^{\text {th }}$ Reference Day', reflected the full implementation of the 2005 Grid and Market Operation Code (RAE, 2014), also provided for a number of 
additional procedures to prevent market abuse, protect the integrity of the market and strengthen public confidence (RAE, 2010: 32).

The electricity market in Greece was opened on $19^{\text {th }}$ February, 2001, but with rather insignificant practical consequences. This was mainly due to the regulated tariffs that the PPC was obliged to apply, since, as they were often below cost, new entry into the supply business was made almost impossible (Iliadou, 2009: 82).

The main responsibility with regard to the energy industry is entrusted to the Minister of Development, which includes the Department of Energy and Natural Resources. The other ministry involved in energy policy issues is the Ministry of Economy and Finance, which is responsible for environmental policy and licensing, while one other public institution is involved in energy issues, the Regulatory Authority for Energy (RAE) (Iliadou, 2009: 77). The RAE is an independent administrative authority, which enjoys, by the provisions of the law establishing it (Law 2773/1999), financial and administrative independence (RAE, 2012).

The powers and responsibilities of the RAE are as follows (RAE, 2012):

1) To monitor and control the operation of the energy market and propose to the competent bodies the necessary measures required to comply with competition rules and consumer protection;

2) To provide opinion regarding the granting of authorisations and control the exercise of rights granted under the authorisations;

3) To collect and evaluate information required for the fulfilment of its duties regarding entities active in the energy sector;

4) To impose fines on violators of this and other acts issued in accordance with this law, including the Grid Code and other Codes;

5) To co-operate with corresponding authorities in other countries or international organisations.

However, RAE lacked full independence and sufficient powers to execute effectively, like many independent regulatory authorities in the world. Thus, a more independent and active role is required by RAE. Moreover, Greece has been in a deep economic crisis, which has operated as a major barrier to use the RAE's full use of its powers and implementation of responsibilities.

\subsection{Characteristics of the Greek Electricity Market}

After the establishment of the PPC in 1950 and its absorption of smaller, local Greek electricity firms after 1956, the Greek electricity industry was organised as a vertically integrated state-owned monopoly. In this monopolistic market, the PPC covered all electricity industry activities in Greece: it owned and operated all the infrastructure and the assets of the industry (Danias et al., 2013: 1040). 
With the structural changes in the Greek electricity market accompanying liberalisation, the PPC was split into two. One firm retained the name 'PPC' and controlled the potentially competitive activities of the market (electricity generation and supply) as well as electricity distribution. The other firm was called the 'Hellenic Transmission System Operator' (HTSO). This firm controlled and operated the electricity transmission system, held the daily electricity auctions and was also responsible for the operation of the wholesale electricity market. These two firms were both further split in 2011 by Law 4001/ 2011, resulting in four firms. The PPC has kept the competitive activities of the market (electricity generation and supply) and a new firm, the Hellenic Electricity Distribution Network Operator (HEDNO), owns and is responsible for the operation of the electricity distribution network. HTSO was also split in two firms, the Operator of Electricity Market (OOEM), which operates the wholesale electricity market, and the Independent Power Transmission Operator (IPTO), which owns and operates the electricity transmission network. However, it is important to point out that the Greek government maintains effective ownership and control over these four firms (Danias et al., 2013: 1041-1042).

\subsection{Performance of the Greek Electricity Market}

Coal and peat are the most important source for electricity generation in Greece, providing 52\% of the total gross generation in 2011. Gas is another power source, providing $23 \%$ in 2011 , with total renewable sources other than hydro providing $9 \%$, hydro $7 \%$ and then oil $9 \%$ of the 2011 total (EIA, 2014a).

Maroulis noted that recent years have seen considerable improvements in relation to the liberalisation of electricity markets. Nevertheless, a properly competitive market is not in place, and the purely dominant monopolistic role of the PPC has been criticized by competitors (Maroulis, et al., 2011: 14), despite a 2007 ministerial decision obliging it to reform the tariff system (OECD/IEA, 2011a: 116).

According to RAE reports and studies, the reluctance of new investors to enter the industry was mainly related to high investment risk due to the market concentration and the institutional and regulatory framework in place (Chalvatzis $\&$ Hooper, 2009: 2705). Thus, reforms to liberalise the wholesale electricity market are underway. The current situation shows the government to be taking several steps, although further progress is needed:

1) Measures to open up the lignite-fired electricity sector are in progress;

2) The awarding of hydro reserves management needs to be further specified;

3) The government has started to implement a new system of regulated tariffs;

4) The unbundling of network activities is experiencing delays (EC, 2011: 36-37). 
Undoubtedly, 2010 was a milestone year for the development and opening up of both the electricity and gas markets in Greece. The electricity wholesale market reached its final structural and operational pattern in September 2010, after the five year transitional period (RAE, 2011: 3).

The electricity retail market became fully open in 2007, and there has been some progress in reforming retail tariffs, such as deregulation for larger customers and the separate identification of public service obligation costs and network charges. However, below-cost tariffs and cross-subsidies are major impediments to competition in electricity supply, as has been witnessed over past few years (OECD/IEA, 2011b: 120). In the midst of its severe economic crisis, Greece liberalised low-voltage electricity tariffs. In order to protect vulnerable consumers (suffering from energy poverty), the government introduced the Social Household Tariff (SHT) in January 2011, giving a discount of approximately $40 \%$ from the normal household bill on annual consumption of up to 5000 kilowatt hours (EIA, 2014b: 41).

Meeting the obligations under the third EU Electricity Market Directive will improve the current situation. Another area where reform is urgently needed is in moving to cost-reflective end-user tariffs. A strong and independent regulator is required to mitigate PPC's dominance, ensure non-discriminatory treatment for independent power producers (IPPs) and provide regulatory certainty for investors in a competitive energy market. In general, investment and competition are needed to ensure the financial efficiency of the electricity sector (OECD/IEA, 2011a: 10).

\section{Policy Changes, Characteristics and Performance of the Turkish Electricity Industry}

\subsection{Policy Changes}

Electricity restructuring has been driven by a privatisation strategy and the revenues that can be generated from privatisation rather than a desire to instil healthy competition in the sector. The key strategic role given to privatisation in the restructuring process has also led the Turkish authorities to initiate restructuring in the distribution segment, where the possibilities of competition are limited, rather than generation, where the real productivity gains would be expected in the medium term (Atiyas et al., 2012 : 7). In this regard, the first restructuring attempt can be mentioned to have been fulfilled in 1993 by the unbundling of the sector-dominating state-owned Turkish Electricity Authority (TEK) into two entities, the Turkish Electricity Generation and Transmission Co. (TEAS) and Turkish Electricity Distribution Co. (TEDAS). TEAS was given responsibility for the generation, transmission and wholesale supply of electricity, while TEDAS undertook the distribution activities (Karahan \& Toptas, 2013: 615).

During the late nineties, the candidacy for EU accession application process provided the main structure for the steps taken. Thus, power sector reform was designed from the start within the framework of EU accession, and harmonization 
of energy legislation with the corresponding EU legislation gave impetus to liberalisation efforts in the power sector (Erdogan, et al., 2008: 1). In February 2001, the Turkish Electricity Market Law (Law No. 4628) was enacted. This provided a new and a radically different legal framework for the design of electricity markets and established the Energy Market Regulatory Authority (EMRA) (Cetin and Oguz, 2007: 1764). The main objective of the law can be stated as "providing affordable, sustainable and quality electricity to consumers in a competitive environment" (Karahan \&Toptas, 2013: 615).

According to the law of 2001, in cases where consumers in certain regions and/or in line with certain objectives need to be supported, such subsidy is provided in the form direct cash refunds to consumers without affecting prices. The amount, procedure and principles of these refunds are established by the Council of Minister upon the proposal of Ministry of Energy and Natural Resources (Özkıvrak, 2005: 1345). In fact, the idea that subsidies would not affect prices was not really a logical expectation, and this kind of implementation was not in compliance with liberalisation efforts.

With the enactment of Electricity Market Law, the Turkish Electricity Generation \& Transmission Co. (TEAS) was unbundled into three state-owned enterprises: TEIAS (Transmission), TETAS (wholesale) and EUAS (Generation) (Durakoğlu, 2011: 5582). According to Law No. 3154, the purpose of the Ministry of Energy and Natural Resources (MENR) is to help define targets and policies related to energy and natural resources in a way that serves and guarantees the defence of Turkey, promotes its security and welfare, strengthens its economy and ensures that energy and natural resources are researched, developed, generated and consumed in a way that is compatible with these targets and related policies (MENR, 2014).

EMRA has administrative and financial autonomy in theory, like many independent regulatory authorities in Turkey. In fact, however, most of the independent regulatory authorities have lacked full independence to effectively execute their roles. In addition to electricity and natural gas markets, EMRA regulates the petroleum and LPG markets and, moreover, collects revenues from these markets. It collects its revenues principally from electricity and gas licensing fees and from a (maximum 1\%) surcharge on electricity transmission, the Third Party Access tariff (TPA). The main functions of EMRA include:

1) Setting up and maintaining a new licensing framework,

2) Preparing secondary legislation,

3) Enforcing regulated third party access (rTPA),

4) Applying a new transmission and distribution code,

5) Determining eligible customers over time, 
6) Regulating tariffs for transmission and distribution activities, as well as provision of retail services to noneligible customers,

7) Regulating the wholesale tariff of TETAS,

8) Performing tenders for gas distribution networks,

9) Monitoring the performance of all actors in the market,

10) Protecting customer rights,

11) Applying sanctions to parties that violate the rules (Erdogdu, 2007: 987).

Since Law 4628 took effect on $3^{\text {rd }}$ March, 2001, Turkey has taken substantial steps toward creating a competitive and functioning market in the electricity energy sector, restructuring public institutions operating in the sector and implementing market rules to ensure its liberalisation. A short- and medium-term roadmap for sector reform and privatisation, the Electricity Energy Sector Reform and Privatisation Strategy Paper was made public on March $17^{\text {th }}, 2004$. Within the scope of this plan, required regulations were finalised, transitional balancing and reconciliation initiated, transitional contracts finalised, the price equalisation mechanism initiated, the State Hydraulic Works (DSI) power plants transferred to EUAS, EUAS portfolio groups formed in preparation for privatisation, TEDAS included in the privatisation programme and tender procedures initiated after establishing the methodology for privatising distribution. Creating a competitive market in the electricity energy sector requires a transitional period. To this end, a transitional period was established in July 2008 through Law 5784 of 09.07.2008 (EMRA, 2010: 104), and the Electricity Energy Market and Supply Security Strategy Paper (2009) was drafted, keeping in mind transitional needs and actions (DPT, 2009: 3).

The Turkish parliament decided to further improve the electricity market structure and in March 2013 introduced a new market law, Law No. 6446, while Law No. 4628 became an organisational law for EMRA. Law No. 6446 determines the framework of the Turkish electricity market. The electricity market is based on bilateral agreements complemented with the balancing and settlement market. The private sector may participate in all segments of the electricity market, except for transmission, by obtaining relevant licenses from EMRA. Non-discriminatory third party access to the network also falls under the supervision of EMRA. Market activities other than, network activities are also open to competition under the supervision and regulation of EMRA (Gözen, 2014: 275-76).

Erdogan et al. (2008: 6) suggested that the Balancing and Settlement Regulation (BSR) can be considered a milestone on the road of liberalisation, since for the first time in the history of the country, electricity prices were allowed to evolve in the market. 
The balancing and settlement system began to operate as of August 2006. Since then, electricity spot prices have been established by market forces. The final balancing and settlement system has been in operation since December 1, 2011. The new system is based on day-ahead market and hourly settlement with the participation also of the demand side. According to the new system, two sets of marginal prices are determined and published: one is for the day-ahead market and the other for real-time balancing.

Although the legal framework and market design are in place and mainly comply with that of the EU, Turkey faced some difficulties in applying the legislation. Consequently, policymakers in Turkey opted for a transitional period before the market structure as outlined in the Law No. 6446 is fully applied. Difficulties resulting from the dominant position of state-owned enterprises, incomplete privatisation of state-owned generation, high level of technical and commercial losses in the network, and the stranded liabilities of the previous period due to agreements of built-operate, built-operate-transfer and transfer of operating rights were signed between the Turkish government and private investors. As part of the transitional period in electricity retail sales, a national tariff system supported by a price equalisation mechanism is being applied all over Turkey until the end of 2015 (Gözen, 2014: 275-76).

Turkish electricity market legislation can be categorised into three groups (Herdem, 2014: 11):

1) Electricity Market Law

- Electricity market opened to competition and to private sector companies,

- Energy stock exchange (EPİAŞ) established,

- Wholesale and retail licenses combined under supply license,

- Pre-license procedure established for manufacturing license applicants,

- Privatization of electricity distribution and manufacturing authorities regulated.

2) Electricity Market Licence Regulation

- License requirement for each market activity established,

- License exemptions provided to stated electricity manufacturers,

- License application procedures regulated.

- Consumers option to determine supplier protected (through 28.01.2014 amendment).

3) Unlicensed Power Generation Regulation

- License exemptions for electricity manufacturers regulated.

- Cogeneration units made not subject to $1 \mathrm{MW}$ installed capacity limit,

- Examination terms for connection applications regulated,

- Purchase guarantee of surplus manufactured electricity regulated,

- Transformation from licensed manufacturing into unlicensed manufacturing under certain conditions enabled. 


\subsection{Characteristics of the Turkish Electricity Market}

In 2001, the government enacted the Electricity Market Law to set up a comprehensive electricity reform program. Under the law, the state-owned Turkish Electricity Generation and Transmission Corporation (TEAS) was split into separate generation, transmission, distribution and trade companies, with a goal of eventual privatisation of the generation and trade companies. Turkey has taken steps to create competitive wholesale trading and retail sales markets and plans to open the market for all customers by 2015. In addition, retail tariffs were changed to reflect the cost of generation, transmission and distribution without subsidies.

The 2001 law created the Energy Markets Regulatory Authority (EMRA) as the regulator of the electricity market. It is tasked with issuing licenses for all market activities related to the electricity market, determining and approving regulated tariffs, and setting the eligibility limit for market opening. In addition, it is involved in drafting legislation affecting electricity markets, resolving disputes, and applying penalties. In March 2013, the Turkish government passed a new Electricity Market Law, establishing an independent regulatory and auditing mechanism for the electricity market.

The largest generation company is the state-owned Electricity Generation Company (EUAS), which controls about half of all generation in Turkey. The remaining generation is provided by independent power producers and firms given special state concessions to build and operate power plants.

Turkish Electricity Transmission Company (TEIAS) is the publicly owned enterprise that owns and operates the transmission system and is legally unbundled (EIA, 2014c: 13).

\subsection{Performance of the Turkish Electricity Market}

In 2012, the total installed capacity in Turkey was 56.1 GWe. In 2011, Turkey's electricity generation came from three main sources: gas $(45.3 \%)$, coal and peat $(28.8 \%)$ and hydro (22.81\%) (EIA, 2014a).

The electricity market was launched on March 3, 2003. All customers directly connected to the transmission system as well as consumers with consumption of more than $4.500 \mathrm{kWh} /$ year for 2014 are deemed eligible. The corresponding theoretical degree of market opening on the demand side is $85 \%$. Under the provisions of Laws No. 4628 and 6446, EMRA lowered the eligibility limit from 9 million $\mathrm{kWh} /$ year in 2003 to $4.500 \mathrm{kWh} /$ year in 2014. In order to enhance market openness on the consumption side, it was expected that the limit would reach zero for all consumers by the beginning of 2015, meaning that all consumers would be free to select their own power suppliers from 2015 (Gözen, 2014: 276- 77).

Electricity prices in Turkey covered the substantial cross-subsidisation from consumers in the western regions to those in the eastern and also from industrial users to households. Actually, EMRA, TEDAS, the Treasury and the Ministry of 
Energy and Natural Resources reached an agreement on transition from the national tariff structure applied in Turkey to the regional tariff structure, but the government did not accept this agreement due to political pressures by consumers in the east (Özkıvrak, 2005: 1348). This implementation thus became a major obstacle for the liberalisation effort, besides EMRA's independence.

A trial synchronous parallel connection of the Turkish national electricity system operated by TEIAS to the ENTSO-E Continental Synchronous Regional Network of Europe was enacted on September $18^{\text {th }}, 2010$. In the near future, the Turkish national electricity network was to allow international trading of the electrical energy in a synchronous parallel connection with the Greek and Bulgarian national networks. Making the national electricity network synchronous with other networks requires amendments in the electricity market legislation with respect to the international trading of electricity. In this context, a revision was planned in the Electricity Market Import and Export Regulation (EMRA, 2010: 2627). In September 2013, the synchronous trial operation of the Turkish system with the system of Continental Europe was formally extended by one year. In its meeting on 16 October 2013, ENTSO-E Regional Group continental Europe approved the document 'Risk assessment for the interconnection of Turkey to the Central European Synchronous Zone' of Project Group Turkey, and concluded that the risk of interconnected operation was acceptable (ENTSOE, 2013: 16).

4. Comparison of the Experience of Regulation and Restructuring in the Greek and Turkish Electricity Industries

First of all, it should be noted that figures up until no later than 2013 are used here, when, as remains the case, the restructuring efforts in the two countries had not yet been completed. The important restructuring measures in this study show that electricity prices have been quite stable over the last few years for both countries. Table 1 gives the data on recent electricity prices for household consumers and industrial consumers.

Table 1. Electricity prices for household consumers and industrial consumers (Euros per kWh)

\begin{tabular}{|c|c|c|c|c|c|c|c|c|}
\hline & \multicolumn{2}{|c|}{2010} & \multicolumn{2}{|c|}{2011} & \multicolumn{2}{|c|}{2012} & \multicolumn{2}{|c|}{2013} \\
\hline & 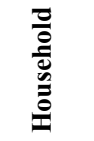 & 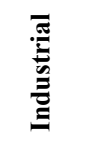 & $\begin{array}{l}\text { 흥 } \\
\text { 윰 } \\
0 \\
0 \\
0\end{array}$ & 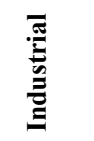 & 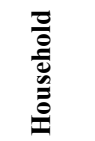 & 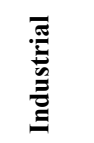 & 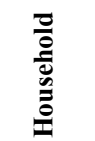 & 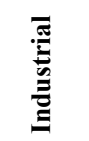 \\
\hline Greece & 0.0975 & 0.0855 & 0.1025 & 0.0917 & 0.1065 & 0.1006 & 0.1170 & 0.1040 \\
\hline Turkey & 0.1067 & 0.0863 & 0.0978 & 0.0863 & 0.1044 & 0.0831 & 0.1186 & 0.0891 \\
\hline
\end{tabular}

Source: Eurostat (2014). 
The data on electricity prices show that industrial customers pay lower prices than household consumers in Greece and Turkey, but that while that gap has contracted in Greece, it has slightly expanded in Turkey. Calculating the household/industrial price ratios for Greece and Turkey for the four years 2010-13 shows small changes. These are 1.14, 1.11, 1.05 and 1.12 for Greece, and for Turkey, 1.23, 1.13, 1.25 and 1.33.

This suggests that electricity price levels do not reflect any price competition at all. Rather, the price levels reveal the Greek and Turkish government policies, which aim to protect electricity consumers, effectively creating a serious barrier to entry for new entrants and thus working against profitable investment opportunities in the industry. It could be suggested that the price levels are the first important challenge for the incumbents and potential entrants in these markets. Meanwhile, consumers may be adversely affected as measures are undertaken to correct for past mistakes. Thus, there is a somewhat paradoxical problem requiring resolution.

There was a widespread political belief that the opening of energy markets to competition would lead to lower prices. This is a fallacy: prices merely reflect the interplay between supply and demand. The market mechanism does not guarantee absolute price levels. Moreover, the sector inherited a monopolistic structure from the past. Legal liberalisation cannot set economic realities aside. Still, confronted by political impatience and dissatisfaction, competition regulators and authorities are called upon to intervene (Woude, 2008: 27).

Although a considerable restructuring of the electricity industries has occurred in Turkey and Greece since 2001, a competitive market is not yet functional. The electricity market in Greece is still very concentrated, because the PPC is still the dominant market player. There are the two main electricity generating companies in Turkey, which presents, therefore, quite a similar case to Greece. The biggest electricity producer in this country is the state-owned EUAS. Thus, market power may be considered as the second challenge in these countries. On the other hand, the negative effects of market power appear narrow because of the public dominance and various restrictions although, with a new market structure, some of the electricity generators might start to define market prices. Therefore, it may be possible to develop the relation between market power and high prices. This, thus, represents the third potential challenge for these sectors.

Sustainable price competition in the generation market requires that generators have excess capacity. Even excess capacity, however, will not suffice to effect competition when there are few generators sharing that capacity (Haas \& Auer, 2006: 863). In the present cases, neither the Turkish nor Greek electricity sector have excess capacity, they also have few generators sharing the existing capacity. This result indicates another challenge for these markets.

Indeed, Greece's electricity generation has failed to meet the total net consumption (Table 2). Clearly, further investment in Greece's electricity generation is required, but for this, investors need to be convinced about the 
regulatory framework. Turkey electricity generation is seen to be enough to meet the total net consumption.

Table 2. Main indicators for Turkish and Greek electricity industry (2011)

\begin{tabular}{|l|ccc|}
\hline & $\begin{array}{c}\text { Total Installed } \\
\text { Capacity }\end{array}$ & $\begin{array}{c}\text { Electricity } \\
\text { Generation }\end{array}$ & $\begin{array}{c}\text { Total Electricity } \\
\text { Net Consumption }\end{array}$ \\
\hline Greece & (Billion Kilowatts) & (Billion KWh) & (Billion KWh) \\
\hline Turkey & 16.5343 & 55.96 & 56.372 \\
\hline
\end{tabular}

Source: IEA (2014a).

Table 3 presents data on the number of companies representing at least $95 \%$ of net electricity generation at national level. In Greece, this number remained stable between 2003 and 2007 and slightly increased between 2008 and 2010, while in Turkey it declined. Table 3 does not suggest a competitive situation.

Table 3. Number of Generating Companies Representing at least $95 \%$ of Net ElectricityGeneration

\begin{tabular}{|c|c|c|c|c|c|c|c|c|c|c|}
\hline & $\mathbf{2 0 0 3}$ & $\mathbf{2 0 0 4}$ & $\mathbf{2 0 0 5}$ & $\mathbf{2 0 0 6}$ & $\mathbf{2 0 0 7}$ & $\mathbf{2 0 0 8}$ & $\mathbf{2 0 0 9}$ & $\mathbf{2 0 1 0}$ & $\mathbf{2 0 1 1}$ & $\mathbf{2 0 1 2}$ \\
\hline Greece & 1 & 1 & 1 & 1 & 1 & 2 & 3 & 4 & $:$ & $:$ \\
\hline Turkey & 148 & 172 & 29 & 30 & 36 & 39 & 69 & 60 & 60 & 54 \\
\hline
\end{tabular}

Source: Eurostat (2014).

Table 4 shows that electricity generation gradually increased in Turkey and Greece between 2001 and 2008, but, slightly decreased between 2008 and 2012. Net electricity generation in Turkey, was quadrupled that of Greece in 2012. It can be suggested that electricity generation did not show a significant improvement in Greece since the reform year.

Table 4. Net Electricity Generation, 2001-2012 (1000 GWh)

\begin{tabular}{|c|c|c|c|c|c|c|}
\hline & $\mathbf{2 0 0 1}$ & $\mathbf{2 0 0 2}$ & $\mathbf{2 0 0 3}$ & $\mathbf{2 0 0 4}$ & $\mathbf{2 0 0 5}$ & $\mathbf{2 0 0 6}$ \\
\hline Greece & 49.7 & 50.6 & 54.3 & 54.9 & 55.7 & 56.5 \\
\hline Turkey & 116.3 & 123.7 & 135.2 & 145.1 & 155.5 & 169.5 \\
\hline & $\mathbf{2 0 0 7}$ & $\mathbf{2 0 0 8}$ & $\mathbf{2 0 0 9}$ & $\mathbf{2 0 1 0}$ & $\mathbf{2 0 1 1}$ & $\mathbf{2 0 1 2}$ \\
\hline Greece & 59.1 & 59.4 & 56.1 & 53.4 & 53.9 & 53.7 \\
\hline Turkey & 183.3 & 189.8 & 186.6 & 201.4 & 218.6 & 228.1 \\
\hline
\end{tabular}

Note: Gwh, gigawatt hours

Source: Eurostat $(2012,2014)$.EIA (2014a). 
In order to make the electricity market work efficiently, it is very important to have accurate data on electricity costs. To deal with this problem, regulators should create and monitor mechanisms through which electricity firms should provide accurate information.

Table 5. Total Number of Electricity Retailers to Final Consumers

\begin{tabular}{|l|c|c|c|c|c|c|c|c|c|c|}
\hline & $\mathbf{2 0 0 3}$ & $\mathbf{2 0 0 4}$ & $\mathbf{2 0 0 5}$ & $\mathbf{2 0 0 6}$ & $\mathbf{2 0 0 7}$ & $\mathbf{2 0 0 8}$ & $\mathbf{2 0 0 9}$ & $\mathbf{2 0 1 0}$ & $\mathbf{2 0 1 1}$ & $\mathbf{2 0 1 2}$ \\
\hline Greece & 5 & 4 & 4 & 4 & 2 & 2 & 3 & 11 & - & 14 \\
\hline Turkey & 5 & 130 & 165 & 245 & 263 & 317 & 362 & 466 & 647 & 767 \\
\hline
\end{tabular}

Source: Eurostat (2014).

Table 5 presents information on the total number of retailers that sold electricity to final customers between 2003 and 2012. While the total number of retailers remained quite stable, with their low number revealing an anticompetitive retailer structure in Greece, the total number of electricity retailers rocketed in Turkey (from 5 to 767 companies), suggesting a competitive improvement. However, checking the numbers of the major electricity retailers (Eurostat, 2014), it is shown to indicate rather that the retailers have monopolistic position in Greece and oligopolistic position in Turkey.

Table 6 presents another important set of data for the restructuring of the electricity sector. This indicates that both Turkey and Greece were able to achieve a significant reduction in electricity transmission and distribution losses following reform. The transmission and distribution losses rate of these countries electricity sector in 2011 is actually lower than it was at the beginning of the reform year. Clearly, the restructuring and regulation efforts made a positive contribution in this area.

Table 6. Electric Power Distribution Loss (\% of output)

\begin{tabular}{|c|c|c|}
\hline Year & TURKEY & GREECE \\
\hline $\mathbf{2 0 0 1}$ & 19.00916684 & 9.314944608 \\
\hline $\mathbf{2 0 0 2}$ & 18.49459042 & 7.376031143 \\
\hline $\mathbf{2 0 0 3}$ & 17.10899766 & 8.507037389 \\
\hline $\mathbf{2 0 0 4}$ & 15.42356236 & 8.839882339 \\
\hline $\mathbf{2 0 0 5}$ & 14.84600756 & 9.419960624 \\
\hline $\mathbf{2 0 0 6}$ & 14.07268334 & 8.474717094 \\
\hline $\mathbf{2 0 0 7}$ & 13.91066935 & 7.749836552 \\
\hline $\mathbf{2 0 0 8}$ & 13.85005393 & 8.031854018 \\
\hline $\mathbf{2 0 0 9}$ & 14.88152681 & 5.275477134 \\
\hline $\mathbf{2 0 1 0}$ & 14.30911708 & 6.594383531 \\
\hline $\mathbf{2 0 1 1}$ & 14.11071829 & 4.765767593 \\
\hline
\end{tabular}

Source: The World Bank (2014). 
Table 7 shows regulatory scores which give a cross comparison of the two cases and the recent indicators of their performance in a number of area. The electricity industries became gradually more competitive in the two countries after 2003, as shown by the entry and vertical integration scores. The public ownership indicator, however, shows a contrary result. Additionally, the structure indicator presents a still anticompetitive market structure, although this has shown improvement since 2001. The regulatory scores are not very different between the two countries. It may be suggested, therefore, that the less restrictive structure may not guarantee a competitive electricity market at all. Anticompetitive structure and conduct can be results of barriers to entry and public ownership. Based on this knowledge, it can be asserted that there are contradictions between the reform programme aims and their implementation results in both countries. Thus, their reform programmes and also their implementation methods should be revised.

Table 7. Comparison of Greek and Turkish Electricity Restructuring and Regulation Performance

\begin{tabular}{|l|c|c|c|c|c|c|c|c|}
\hline Years & \multicolumn{2}{|c|}{ Entry } & \multicolumn{2}{c|}{$\begin{array}{c}\text { Public } \\
\text { Ownership }\end{array}$} & \multicolumn{2}{c|}{$\begin{array}{c}\text { Vertical } \\
\text { Integration }\end{array}$} & \multicolumn{2}{c|}{$\begin{array}{c}\text { Sector } \\
\text { Indicator }\end{array}$} \\
\hline & Greece & Turkey & Greece & Turkey & Greece & Turkey & Greece & Turkey \\
\hline $\mathbf{1 9 9 0}$ & 6.0 & 6.0 & 6.0 & 6.0 & 6.0 & 6.0 & 6.0 & 6.0 \\
\hline $\mathbf{1 9 9 1}$ & 6.0 & 6.0 & 6.0 & 6.0 & 6.0 & 6.0 & 6.0 & 6.0 \\
\hline $\mathbf{1 9 9 2}$ & 6.0 & 6.0 & 6.0 & 6.0 & 6.0 & 6.0 & 6.0 & 6.0 \\
\hline $\mathbf{1 9 9 3}$ & 6.0 & 6.0 & 6.0 & 6.0 & 6.0 & 6.0 & 6.0 & 6.0 \\
\hline $\mathbf{1 9 9 4}$ & 6.0 & 6.0 & 6.0 & 6.0 & 6.0 & 6.0 & 6.0 & 6.0 \\
\hline $\mathbf{1 9 9 5}$ & 6.0 & 6.0 & 6.0 & 6.0 & 6.0 & 6.0 & 6.0 & 6.0 \\
\hline $\mathbf{1 9 9 6}$ & 6.0 & 6.0 & 6.0 & 6.0 & 6.0 & 6.0 & 6.0 & 6.0 \\
\hline $\mathbf{1 9 9 7}$ & 6.0 & 6.0 & 6.0 & 6.0 & 6.0 & 6.0 & 6.0 & 6.0 \\
\hline $\mathbf{1 9 9 8}$ & 6.0 & 6.0 & 6.0 & 6.0 & 6.0 & 6.0 & 6.0 & 6.0 \\
\hline $\mathbf{1 9 9 9}$ & 6.0 & 6.0 & 6.0 & 6.0 & 4.5 & 6.0 & 5.5 & 6.0 \\
\hline $\mathbf{2 0 0 0}$ & 6.0 & 6.0 & 6.0 & 6.0 & 4.5 & 6.0 & 5.5 & 6.0 \\
\hline $\mathbf{2 0 0 1}$ & 2.3 & 4.0 & 6.0 & 6.0 & 4.5 & 1.5 & 4.3 & 3.8 \\
\hline $\mathbf{2 0 0 2}$ & 2.3 & 2.3 & 4.5 & 6.0 & 1.5 & 1.5 & 2.8 & 3.3 \\
\hline $\mathbf{2 0 0 3}$ & 2.3 & 0.3 & 4.5 & 6.0 & 1.5 & 1.5 & 2.8 & 2.6 \\
\hline $\mathbf{2 0 0 4}$ & 2.3 & 0.3 & 4.5 & 6.0 & 1.5 & 1.5 & 2.8 & 2.6 \\
\hline $\mathbf{2 0 0 5}$ & 0.3 & 0.3 & 4.5 & 6.0 & 1.5 & 1.5 & 2.1 & 2.6 \\
\hline $\mathbf{2 0 0 6}$ & 0.3 & 0.3 & 4.5 & 6.0 & 1.5 & 1.5 & 2.1 & 2.6 \\
\hline $\mathbf{2 0 0 7}$ & 0.3 & 0.3 & 4.5 & 6.0 & 1.5 & 0.0 & 2.1 & 2.1 \\
\hline $\mathbf{2 0 4 5}$ & & & & & & & \\
\hline
\end{tabular}

Source: OECD (2012).

Note: 0 to 6 scale from least to most restrictrive of competition. These indicators are described in: Conway, P. and G.Nicoletti (2006). 
When the policy changes in the Greek and Turkish electricity sectors are evaluated, both existing and potential problems are identified. Unfortunately, no substantial adjustments have been made to cope with the challenges that have been revealed. The power and responsibilities of the (Greek) RAE are narrower than those of the (Turkish) EMRA, it may also be noted. The RAE requires wider powers and greater autonomy in exerting them.

Electricity reform in the two countries is still in the transitional period. However, instead of continuing to move forward, they have both postponed their plans due to various internal and external economic and political factors. Therefore, inevitably, adjustments in policy, operational paradigm and institutional reform will become necessary.

As Kalantzis and Sakellaris (2012: 8) state, policy makers should continuously monitor the results of these reforms and be prepared to modify or even cancel reforms that do not lead to the expected results Turkey and Greece should take this advice into consideration, and they should strengthen their implementation of its recommendations.

Clearly, when the two countries come to the end of transitional period, they will still require a deregulation process. Hence, they need to look beyond the transitional period.

\section{Conclusion}

Although considerable restructuring of the electricity industries has occurred in Greece and Turkey, it has not been completed and a competitive market has not been functional yet. Both countries' electricity industries are facing the challenge of completing the liberalisation process regarding price levels and existing and potential market power in the generation and retailer segments. These challenges require an industry that is strong in terms of independent regulatory conduct and thus capable of making strong commitments.

In summary, the electricity industries in Turkey and Greece have undergone a radical restructuring, which is still an ongoing process. There is a requirement for persistent work. Electricity industry restructuring and regulation is a complex task, and policymakers clearly need to continue their efforts toward competitive and more efficient electricity industries. Most importantly, the institutional and political reforms that can ensure the smooth functioning of the electricity industries need to be enacted. Policymakers will need to face the facts to find systemic solutions rather than taking politically safe and opportunistic actions. A debate about regulatory principles for the Greek and Turkish electricity markets is crucially needed, in which, alongside the essential objectives of customer protection and ensuring fair competition, concepts such as regulator independence, results-orientation and investment incentives must also be key elements. 


\section{References:}

Andrianesis, P., Biskasb\& P., Liberopoulos, G., (2011), 'An overview of Greece's wholesale electricity market with emphasis on ancillary services', Electric Power Systems Research, Vol.81,No.8, pp. 1631-1642.

Atiyas, I., Çetin, T. \& Gülen, G., (2012), Reforming Turkish Energy Market- Political Economy, Regulation and Competition in the Search for Energy Policy, Springer, New York.

Avrupa Komisyonu, (2011), Türkiye 2011 Yllı Ilerleme Raporu, Avrupa Komisyonu, Brüksel.

Camadan, E., (2011), 'Why 2012 will be so important for the Restructured Turkish Electricity Market', The Electricity Journal, Vol.24, No.10, pp. 70-78.

Cetin, T. \& Oguz, F., (2007), 'The Politics of Regulation in the Turkish Electricity Market', Energy Policy, Vol.35,No.3, pp. 1761-1770.

Chalvatzis, K. J. \& Hooper, E., (2009), 'Energy security vs. climate change: Theoretical framework development and experience in selected EU electricity markets', Renewable and Sustainable Energy Reviews, Vol.13,No.9, pp. 2703-2709.

Conway, P. \& Nicoletti, G., (2006), 'Product market regulation in non-manufacturing sectors in OECD countries: measurement and highlights', OECD Economics Department Working Paper No.530.

Danias, N., Swales, J. K. \& McGregor, P., (2013), 'The Greek Electricity Market Reforms: Political and Regulatory Considerations', Energy Policy, Vol.62, pp. 1040-1047.

DPT, (2009), Electricity Energy Market and Supply Security Strategy Paper, Higher Board of Planning, Ankara.

Durakoglu, S. M., (2011), 'Political Institutions of Electricity Regulation: The Case of Turkey', Energy Policy, Vol.39, No.9, pp. 5578-5587.

Energy Market Regulatory Authority (EMRA), (2010), Electricity Market Report, http://www.epdk.gov.tr/documents/elektrik/rapor_yayin/ElectricityMarketReport2010.p df, Retrieved on: December 5, 2011.

EIA

(2014a),

'International

Energy

Statistics', http://www.eia.gov/countries/data.cfm Retrieved on: May 23, 2014.

EIA, (2014b), 'Policies that Work', Electricity -Journal of International Energy Agency, Issue 6- 2nd quarter, $\quad$ pp. 41http://www.iea.org/media/ieajournal/IEAENERGY_Issue6.pdf, Retrieved on: June 2, 2014.

EIA, (2014c), Turkey Full Report, http://www.eia.gov/countries/cab.cfm?fips=TURetrieved on: May 24, 2014.

ENTSOE, (2013), 'Annual Work Programme 2013-2014', European Network of Transmission System Operators for Electricity, https:/www.entsoe.eu/publications/general-publications/annual-workprogramme/Pages/default.aspx, Retrieved on: February 28, 2014. 
Erdogan, F. H., Cetinkaya, S. \& Dusmez E. T., (2008), 'Market Liberalization Process and Market Arrangements in Turkey', Electricity Market, 2008. EEM, 2008, 5th International Conference European.

Erdoğdu, E., (2007), 'Regulatory Reform in Turkish Energy Industry: An analysis', Energy Policy, Vol.35, No.2,pp. 984-993.

EURELECTRIC, (2011), Power Statistics and Trends 2011 Edition, http://www.eurelectric.org/PowerStats2011, Retrieved on: February 23, 2012.

European Commission (EC), (2011), European Economy, Occasional Papers 77, The Economic Adjustment Programme for Greece, Third Review, Brussels.

Eurostat, (2012), http://epp.eurostat.ec.europea.eu, Retrieved on: September 11, 2012.

Eurostat, (2014), http://epp.eurostat.ec.europa.eu, Retrieved on: May 23, 2014.

Gözen, M., (2014), 'Renewable Energy Support Mechanism in Turkey: Financial Analysis and Recommendations to Policymakers', International Journal of Energy Economics and Policy, Vol. 4, No.2, pp.274-287.

Haas, R. \& Auer, H., (2006), 'The prerequisites for effective competition in restructured wholesale electricity Markets', Energy,Vol.31,No.6-7, pp. 857-864.

Herdem, (2014), 2013 Turkey Energy Report, Herdem Attornays at Law.

HTSO (Hellenic Transmission System $\quad$ Operator (2012), http://www.desmie.grRetrieved on: February 23, 2012.

Iliadou, E.N., (2009), 'Electricity Sector Reform in Greece', Utility Policy, Vol.17, No.1, pp. 76-87.

Jamasb, T., Mota, R., Newbery, D., Pollitt, M., (2004), 'Electricity Sector Reform in Developing Countries: A Survey of Empirical Evidence on Determinants and Performance', Cambridge Working Papers in Economics CWPE 0439.

Kalantzis, F. \& Sakellaris, K., (2012), "Investigating the Impact of the Greek Electricity Market Reforms on its Day-Ahead Market Prices", MPRA Paper No. 37794, pp. 1-10. http://mpra.ub.uni-muenchen.de/37794/1/MPRA_paper_37794.pdf, Retrieved on: October 20, 2013.

Karahan, H. \& Toptas, M., (2013), 'The effect of power distribution privatization on electricity prices in Turkey: Has liberalization served the purpose?', Energy Policy, Vol.63, pp. 614-621.

Koroneos, C. S. \& Nanaki E. A., (2007), 'Electric energy sustainability in the Eastern Balkans', Energy Policy,Vol.35, pp. 3826-3842.

Maroulis, G., Piria, R., Zane, E. B., Frank, R. \& Bauknecht, D., (2011), Integration of electricity from renewables to the electricity grid and to the electricity market - RES INTEGRATION National report: Greece, Berlin.

MENR, (2012), Republic of Turkey Minister of Energy and Natural Resources, http://www.enerji.gov.tr, Retrieved on: March 15, 2012.

MENR, (2014), http://www.enerji.gov.tr, Retrieved on: May 29, 2014. 
OECD, (2001a), OECD Regulatory Reviews of Regulatory Reform, Regulatory Reform in Greece, Regulatory Reform in Electricity, Domestic Ferries and Trucking.

OECD, (2001b), OECD Regulatory Reviews of Regulatory Reform, Regulatory Reform in Greece, Enhanching Market Openness Though Regulatory Reform. http://www.oecd.org/greece/2756295.pdf, Retrieved on: December 3, 2012.

OECD/IEA, (2011a), Energy Policies of IEA Countries - Greece 2011 Review, France. http://www.iea.org Retrieved on: February 8, 2013.

OECD/IEA, (2011b), Energy Policies of IEA Countries - Greece 2011 Review, Executive summary and Key Recommendations.

http://www.iea.org/Textbase/npsum/greece2011SUM.pdf, Retrieved on: February 8, 2013.

OECD, (2012), http://www.oecd.org, Retrieved on: December 3, 2012.

Özkıvrak, Ö., (2005), 'Electricity Restructuring in Turkey’, Energy Policy, Vol.33, 13391350.

RAE, (2010), 2010 National Report to the European Commision, Athens. http://www.rae.gr/old/K2/NR-Greece-2010.pdf, Retrieved on: February 3, 2012.

RAE, (2011), 2011 National Report to the European Commision, Athens. http://www.rae.gr/site/file/system/docs/misc1/20102011/16112011, Retrieved on: February 8, 2012.

RAE, (2012), http://www.rae.gr, Retrieved on: February 3, 2012.

RAE, (2014), http://.www.rae.gr, Retrieved on: February 28, 2014.

Sakellaris, K., Perrakis, K.G. \& Angelidis, G., (2010), 'Evaluating the New Greek Electricity MarketRules', MEDPOWER 2010 Conference, Agia Napa, Cyprus.

The World Bank, (2014), http://data.worldbank.org, Retrieved on: May 23, 2014.

Woude, M., (2008), 'Unfair and excessive prices in the energy sector', European Review of Energy Markets, Vol.2, No.3, pp. 1-29. 


\title{
DÜNYA TİCARET ÖRGÜTÜ KAMU ALIMLARI ANLAŞMASINA GENEL BİR BAKIŞ VE BU ANLAŞMANIN AVRUPA BİRLIĞİ'NDE UYGULANMASI
}

\author{
Servet ALYANAK*
}

\section{$\ddot{O}_{z}$}

Dünya Ticaret Örgütü (DTÖ) Kamu Alımlarl Anlaşması (KAA) dünya ticaretinin serbestleştirilmesine katkı yapmayı ve kamu ihale piyasasinı uluslararası ticaret kurallarının kapsamı altına almayı amaçlamaktadır. Şu anda 42 ülke bu Anlaşmaya taraf olmuştur. Anlaşma bir kamu ihalesine katılan işletmeleri doğrudan muhatap alan çeşitli düzenlemeler içermesi itibariyle yeni bir çı̆̆ır açmıştır. Anlaşma, kendi kapsamına giren ihalelerde, taraf ülkelerin ve tedarikçilerinin yararına olacak şekilde ayırımcılık yapılması yasağı, ulusal muamele, en çok kayırılan ülke ve şeffaflık prensiplerini temel almaktadır. Acaba bu işletmeler KAA'nın ilgili hükümlerini gerekçe göstererek Avrupa Birliği (AB) hukuku bağlamında bu hükümlerin uygulanmasını talep edebilirler mi? Ya da bu işletmeler KAA'dan kaynaklanan haklarını ancak $A B$ yasa koyucusunun kendi iç hukukunu (AB hukukunu) KAA'ya uyumlaştırdiğ oranda ve bu Anlaşma kapsamında kalan yabancı işletmelere Anlaşmada uygulanması öngörülen usuller doğrultusunda mı ileri sürebilecektir? Bu makale okuyucuya KAA hakkında genel bir bakış sağlamakta ve KAA'nın temel niteliklerini gözden geçirmektedir. Bunun yanı sıra makale, KAA'nın bazı hükümlerinin AB Üye Devletlerinin ulusal mahkemelerinde uygulanmasını ileri sürme sorununu da tartışmaktadır. Makalenin ilk kısmı DTÖ KAA'y yluslararası kamu ihale mevzuatı bağlamında analiz etmekte ve bu açıdan önemli noktalara değinmektedir. İkinci kısım, KAA'nın hukuki niteliğ $i$ ve temel özelliklerini incelemektedir.

Anahtar kelimeler: Dünya Ticaret Örgütü, Kamu Alımları Anlaşması, kamu ihaleleri, ayırımcılık yapma yasağı, şeffaflık, ticaretin serbestleştirilmesi.

* Dr. (LL.M, Mag. Iur., Ph.D), Hâkim, Kamu Denetçiliği Kurumu, e-posta: servet.alyanak@ombudsman.gov.tr 